\title{
Distribution and development of some Manx epiphyte populations*
}

\author{
G. Russell \\ Department of Environmental and Evolutionary Biology, The University; Liverpool, \\ L69 3BX, England
}

\begin{abstract}
The success of Elachista fucicola as an epiphyte of Fucus vesiculosus is partly due to its ability to grow on most parts of the host thallus. Its ability to reach reproductive maturity quickly ensures its fitness, even on temporary structures such as receptacles. Epiphyte distribution may also vary with host morphology. Himanthalia elongata is a basiphyte for several tissue-specific epiphytes: Ectocarpus fasciculatus, Elachista scutulata, Herponema velutinum and Myriactula areschougii are exclusive, or almost so, to receptacles. On growing receptacles their specificity extends to conceptacles, which also provide refuges from grazing. Epiphyte abundance in summer is greatest at the upper and lower limits of Himanthalia distribution, suggesting that basiphytes living under suboptimal conditions are more prone to infestation by epiphytes. 5-10\% of Himanthalia receptacles are thought to persist over winter and so to facilitate the transmission of epiphytes to the following year's crop of receptacles. The distribution of Ectocarpus fasciculatus on Laminaria digitata differs in pattern from that on Himanthalia. The two Ectocarpus populations also differ morphologically, but both have reproductive and developmental, characteristics that are in accord with the ecological cycles of their basiphytes. This characteristic is likely to be an important factor in determining the success of an epiphyte. Success may also be facilitated by epiphyte variability or by possession of a fixed but well-adapted phenotype. The very high incidence of brown algal epiphytes on growing Himanthalia receptacles does not reflect the composition of the surrounding algal vegetation. The possibility that some host-recognition mechanism operates cannot be discounted.
\end{abstract}

\section{INTRODUCTION}

The world-wide incidence and species richness of algal epiphytes have excited the interest of phycologists for well over a century, and led to the publication of a large body of literature. This research has been carried out by numerous and diverse methods, but three quite distinct approaches seem to recur with great consistency in the literature.

The oldest of these is primarily floristic in emphasis, a good example being found in the work of Tokida (1960) on the epifloras of the members of the order Laminariales. Other phycologists have preferred to concentrate upon the cellular and metabolic relationships between epiphyte and basiphyte, with the aim of elucidating particular and highly specific associations. The results of this second line of research have been summarized and reviewed recently by Ducker \& Knox (1984).

The third approach, more strictly ecological than the other two, gives greater emphasis to detailed analysis of the structure of the epiphytic community, its pattern of

* Dedicated to Dr. Dr. h. c. Peter Kornmann on the occasion of his eightieth birthday. 
development and susceptibility to biological interactions, particularly grazing. A great deal of this research has been carried out on the epiphyte communities of seagrasses: see Novak (1984) and Orth \& Montfrans (1984) for original observations and literature reviews.

It is not surprising that seagrasses should have proved popular subjects for study. Their leaves form discrete structural modules (sensu Silvertown, 1987) and they are produced in orderly succession. Also, the leaf blades are usually flat, providing a surface upon which the epiphytes may be located and examined with relative ease. However, modularity is not a sole property of seagrasses, it is also evident in some of the larger seaweeds whose structural components may be sufficiently distinguishable to permit comparative studies of epiflora development. For example, the species composition and abundance of algal epiphytes varies with position on the Laminaria stipe and varies with the depth at which the basiphyte is located (Marshall, 1960; Norton et al., 1977). The distribution and abundance of the blade epiphytes, on the other hand, seems to be more strongly related to blade growth characteristics (Russell, 1983a, b).

Quantitative studies of epiphytes are equally possible at the level of the population, although the limits of an epiphyte population may not always be easy to determine. For example, a given species of epiphyte may be represented on a single host plant by many individuals, and thus form a sufficiently circumscribed group to justify recognition as a population. However, the assemblage of basiphytes can also serve to define the epiphyte population on a wider scale. Such problems of definition are perhaps too arcane to justify prolonged debate, but this ought not to obscure a real need to know more about spatial and temporal patterns of epiphyte abundance in relation to those of the basiphyte. When treated in this way, the study of epiphytism becomes, in effect, one of epidemiology. Wetzel (1983), writing in similar vein of freshwater periphyton, has stated that ". . knowledge of the structure and architecture of the community is the foundation for interpretation of its functional characteristics".

The aim of the present exercise was to examine some Manx populations of basiphytes together with those of their brown algal epiphytes, in an attempt to see how particular associations are maintained in nature. Three species of basiphyte were considered: Fucus vesiculosus L., Himanthalia elongata (L.) S. F. Gray and Laminaria digitata (Huds.) Lamour. In fucoid species, reproductive tissue (receptacles) form distinct thallus modules and, consequently, they were treated as separate from vegetative modules. In $L$. digitata, distinction has been made only between stipe and blade. In no species was the holdfast epiflora examined.

\section{FUCUS VESICULOSUS L.}

\section{Basiphyte populations}

Two populations were sampled. The first of these was located at Scarlett Point, a very exposed headland at the south end of the Isle of $\mathrm{Man}_{\text {; }}$ and the second at Hilbre Island, a fairly sheltered site at the mouth of the River Dee in N.W. England. The second population was included because, in common with the Scarlett Point plants, its commitment to reproductive tissue is very high. The reproductive allocation (RA) of both populations (i.e. the dry weight of receptacles expressed as a percentage of total thallus dry weight of each plant) was measured in midsummer when they are most reproductive. 
The mean RA of the Scarlett Point populations calculated from 25 fertile plants was 56.16 (S.D. $= \pm 11.10$ ) and that of 28 Hilbre plants was 68.50 (S.D. $= \pm 7.82$ ): figures based upon data in Russell (1979).

The two populations differ in the way their high RA is expressed; Scarlett Point plants generally produce more numerous but smaller receptacles than those at Hilbre (Fig. 1). They also differ in vegetative morphology. Scarlett Point plants are short with

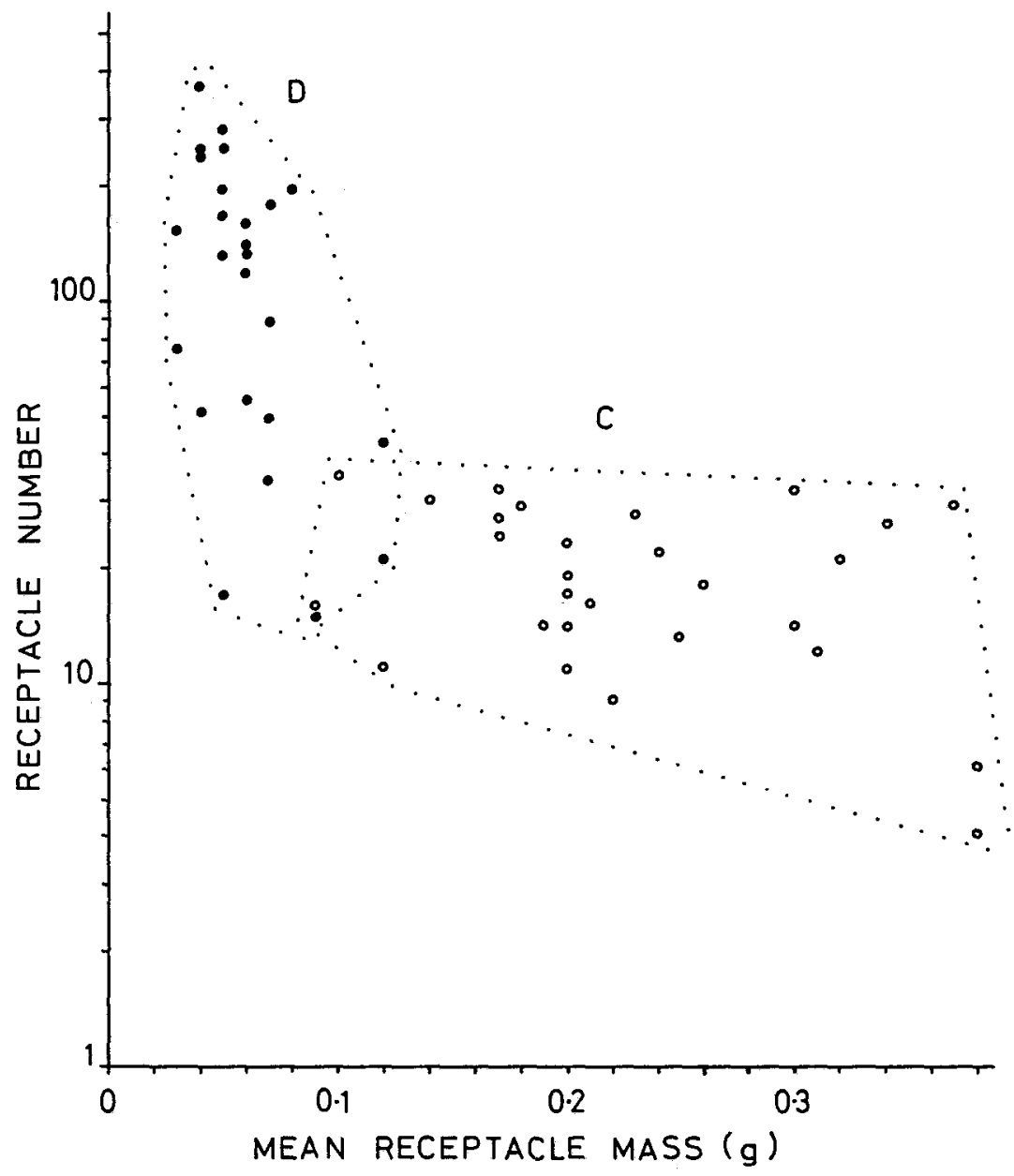

Fig. 1. Scatter diagram showing number of receptacles on each fertile plant of Fucus vesiculosus and their mean dry weight. Closed circles denote population from Scarlett Point (D), and open circles that from Hilbre Island (C)

very robust stipes and the frond is much-branched, narrow and evesiculate. Hilbre plants have smaller stipes, fewer dichotomies, broader fronds and more vesicles.

Fucus vesiculosus is common on most Manx rocky shores. It occupies a broad band of the eulittoral zone and is scarce only in extreme shelter, when it is normally replaced by Ascophyllum nodosum (L.) Le Jol. Nevertheless, it is to be found in sheltered localities 
where there are breaks in the Ascophyllum cover, and in estuarine or muddy conditions. These habitat differences have long been linked with differences in thallus morphology and the various Manx morphs have been described by Knight \& Parke (1950). $F$. vesiculosus is the most common fucoid at Hilbre but the range of habitat types at this locality is small and thallus morphology correspondingly uniform.

\section{Epiphyte populations}

Fucus vesiculosus serves as a basiphyte for numerous species of epiphyte, but three brown algae are particularly frequent. These are Pilayella littoralis (L.) Kjellm., Spongonema tomentosum (Huds.) Kütz., and Elachista fucicola (Vell.) Aresch. None of these is specific to $F$. vesiculosus; but $E$. fucicola is most common on $F$. vesiculosus and Fucus serratus, and most plentiful during summer (Knight \& Parke, 1931).

The spatial distribution of E. fucicola within the two Fucus populations was analysed in May-June 1981 from samples of 45 fertile plants from Scarlett Point and 95 from Hilbre. Each plant was dissected according to 5 tissue categories: vegetative apices, receptacles, receptacle-support tissue, mid-thallus, and stipe (Fig. 2A). The presence of Elachista on these was determined by low-power microscopy. All the less numerous modules, such as the stipes, were examined but very numerous modules were subsampled. The frequency of Elachista in each tissue category was expressed as percentage of the number of modules examined, and the results presented as frequency distribution polygons (Fig. 2 ; C, D).

It is evident from Figure $2 \mathrm{C}, \mathrm{D}$ that mid-thallus modules were very rich in Elachista both in the Hilbre Fucus population (Fig. 2C) and in that from Scarlett Point (Fig. 2D). However, the epiphyte distribution among the other modules was very different. The frequency of stipe epiphytes was high and that of receptacle epiphytes was low in the Scarlett Point sample (Fig. 2D) while the reverse was true of the Hilbre Fucus. These differences are explicable in terms of basiphyte morphology, for Hilbre Fucus has smaller stipes than the Manx population, higher RA and larger receptacles (Fig. 1). However, the differences in Elachista distribution also have implications for the long-term success of the epiphytye. Fucus receptacles are short-lived structures, and they are shed together with their support tissue after the discharge of gametes (Knight \& Parke, 1950). For the Hilbre Elachista population especially, the shedding of spent receptacles must result in considerable losses of individuals. It is likely, therefore, that the fitness of Elachista as an epiphyte will be enhanced by the ability to reach reproductive maturity within the lifespan of a receptacle. This property is possessed by both Elachista populations (Fig. 7a).

It may be concluded then that the spatial distribution of Elachista fucicola is responsive to population differences in basiphyte morphology. It is also probable that the success of this species as an epiphyte of Fucus ist attributable, in part, to the fact that it can colonise a variety of host tissues and, in part, to its rapid reproductive development. In late summer and autumn, when a few old receptacles may remain attached to Fucus thalli, these are usually heavily coated with Elachista and other epiphytes. The importance of heavily epiphytised tissues as sources of further generations of epiphytes may be inferred from the fact that at Hilbre, the Fucus population possesses reproductive tissue for much of the year (Russell, 1985). 


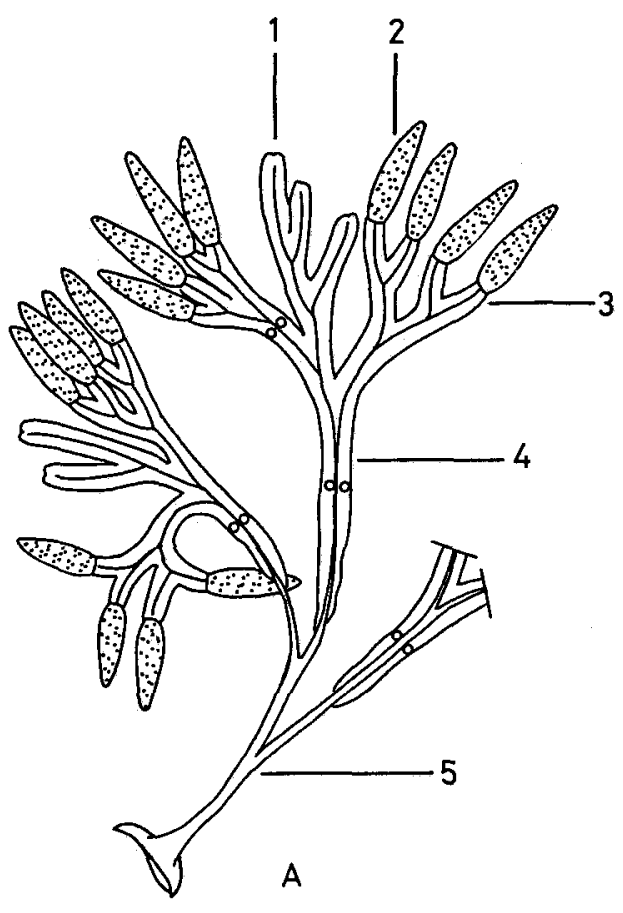

B
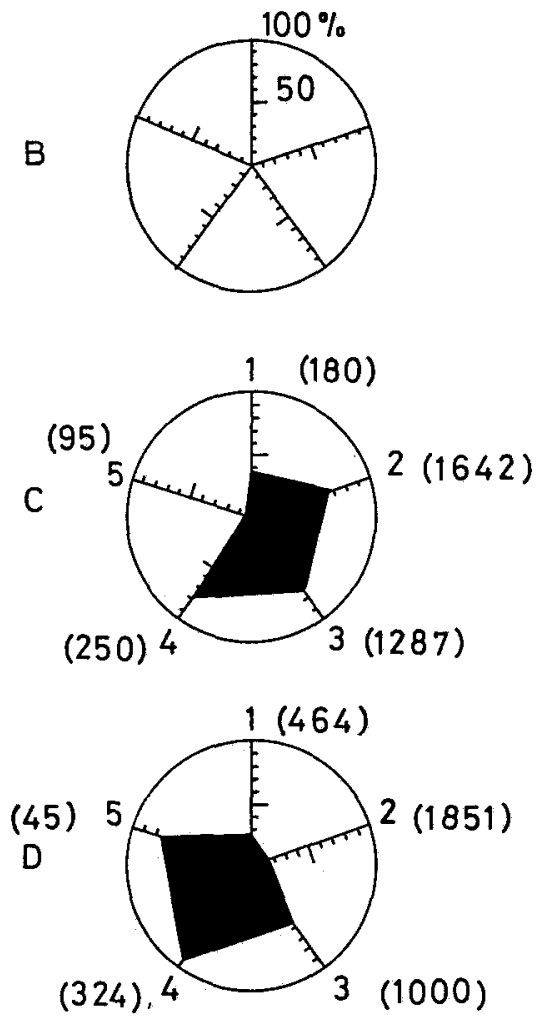

Fig. 2. A: Diagram of Fucus vesiculosus thallus showing positions of five tissue modules $1=$ vegetative apices; $2=$ receptacles; $3=$ receptacle support tissue; $4=$ midthallus; $5=$ stipe). B: Scale of frequency of Elachista fucicola on the tissue modules (1-5). C: Frequency polygon of E. fucicola on F. vesiculosus from Hilbre Island. D: Frequency polygon for Scarlett Point populations. Numbers in parentheses indicate actual numbers of modules examined. Populations sampled in May/June 1981

\section{HIMANTHALIA ELONGATA (L.) S. F. GRAY}

\section{Basiphyte population}

Himanthalis elongata is more narrowly restricted, spatially and in terms of environmental conditions, than Fucus vesiculosus. It is absent from sheltered shores and from muddy or estuarine sites; it is present but not abundantly on very exposed shores. Its preferred Manx habitat seems to be fairly gently sloping rock subject to moderate wave action. In these conditions, it forms a belt approximately $1.5 \mathrm{~m}$ in height in the lower eulittoral and upper sublittoral zones. However, it may occur sporadically in rock pools at higher shore levels.

The modularity of the Himanthalis thallus is more sharply defined than is the case with Fucus vesiculosus. The juvenile vegetative thallus is a small peg-shaped structure which expands into a shallow saucer- or button-shaped thallus when mature. This vegetative thallus is perennial but, unlike that of Fucus, it lacks cryptostomata. Recepta- 
cles of Himanthalia are dichotomously-branched structures arising, usually in pairs, from the centre of each vegetative button. The processes of vegetative thallus development and receptacle maturation have been described by Moss (1952) who states that receptacles may grow to lengths of approximately $2 \mathrm{~m}$. It is probable therefore that the RA of Himanthalia can reach $95 \%$ or more, although measurements on Manx populations have yet to be made.

The locality selected for study is Port St. Mary Ledges, a moderately exposed shore upon which there is a well-developed Himanthalia population. This was sampled in April 1987. Five vertically equidistant positions were marked out within the Himanthalia belt and five replicate quadrats $25 \times 25 \mathrm{~cm}$ were then located randomly, using rope coordinates, at each position. All the Himanthalia was removed from each quadrat and returned to the laboratory where plant fresh weights were obtained. Himanthalia was also collected from a rock pool located above the upper limit of the species on open rock; however, because of substrate irregularity, sampling had to be carried out subjectively.

The 25 open-shore quadrats contained a total of 3144 Himanthalia plants, of which only 181 bore receptacles. There was there fore a huge excess of vegetative plants in the population. The frequency distribution of the fresh weights of the 2963 vegetative plants is given in Figure $3 \mathrm{~A}$, which shows the presence of two fairly distinct peaks. The vegetative thallus weights of the 181 plants which bore receptacles are given in Figure 3B

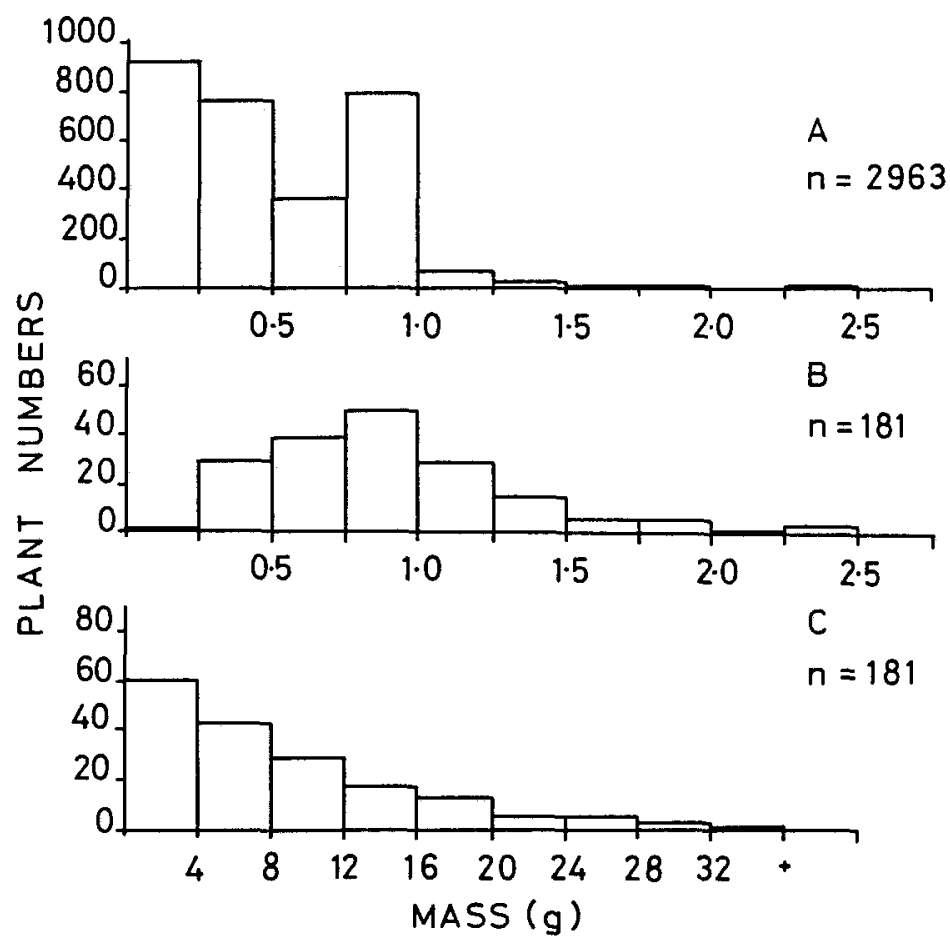

Fig. 3. A: Fresh weights of vegetative thalli of non-reproductive Himanthalia elongata from Port St Mary. B: Fresh weights of vegetative thalli of reproductive Himanthalia in same population. C: Fresh weights of receptacles of Himanthalia in same population. Population sampled in April 1987 
which shows a single maximum, coinciding with the second peak in Figure 3A. These observations suggest that Himanthalia may remain for two years in a vegetative state before entering a reproductive third year as proposed by Gibb (1937). However, this inference must be subject to the usual qualifications about making deductions of age from stage.

The fresh weights of the receptacles in the sample were found (Fig. 3C) to be skewed towards the lightest weight class. The long tail of higher weights is of special interest because it contained those 1986 receptacles which had survived the winter 1986-87.

The quadrat samples revealed quite considerable altitudinal differences in Himanthalia density (Fig. 4A). Densities were low $<1000$ plants $\mathrm{m}^{-2}$ ) at the two upper sites and
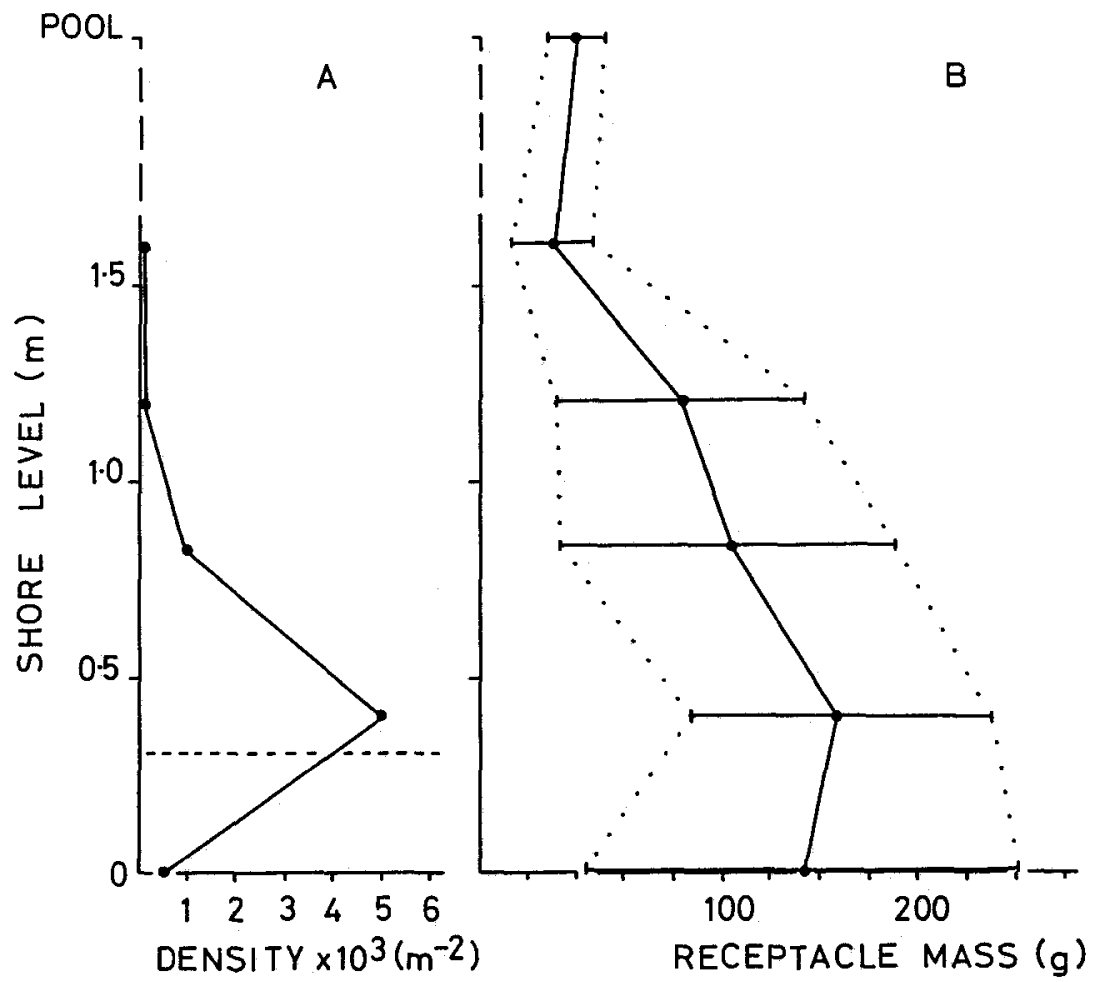

Fig. 4. A: Density of Himanthalia elongata at various positions in its vertical distribution at Port St Mary in April 1987. Hatched line indicates approximate upper limit of Laminaria digitata. B: Fresh weights (Means \pm S. D.) of Himanthalia receptacles at different levels in August 1987

reached a maximum of approximately 5000 plants $\mathrm{m}^{-2}$ just above the upper boundary of the sublittoral zone. However, at the lowest sampling position, in the Laminaria digitata forest, Himanthalia density was again low.

According to Gibb (1937), Manx Himanthalia receptacles reach maximum size in July-August. A second sample of 30 fertile plants from each open-shore position, and 
from the rock pool, was collected in August 1987. The mean receptacle fresh weights and standard deviations are given in Figure 4B. The smallest receptacle weight was recorded in the uppermost of the open-shore positions and in the rock pool. The largest receptacles were found at lower levels; but those from the bottom were very variable, large receptacles occurring in breaks in Laminaria cover and small ones beneath the Laminaria canopy.

\section{Epiphyte populations}

The most common brown algal epiphytes of Manx Himanthalia are: Ectocarpus fasciculatus Harv., Herponema velutinum (Grev.) J. Ag., Elachista scutulata (Sm.) Aresch., and Myriactula areschougii (Crouan frat.) Hamel. The first of these is not specific to Himanthalia but the Herponema, Elachista und Myriactula species have not been reported on other hosts. Specificity extends also to basiphyte tissues, Herponema, Elachista und Myriactula being present only on the host receptacle. Ectocarpus, though almost always present on receptacles, may occasionally be found on the vegetative thallus.

The vertical distributions of Ectocarpus, Herponema and Elachista species in the August 1987 sample are shown in Figure 5A. Epiphyte abundance was calculated as the mean number of epiphyte plants recognisable to the naked eye on each basiphyte. Ectocarpus fasciculatus was most common in the rock pool sample but occurred sporadically throughout its basiphyte range. Herponema velutinum, though absent from the pool, also had a wide vertical distribution but Elachista scutulata was common only in the lower parts of the range.

The relative numbers of brown algal epiphytes and those belonging to the green and red algae (expressed as percentages of the total numbers) are given in Figure 5B. It is evident that red and green algae together accounted for only a small minority of the total number of epiphyte plants present at each position.

Microscopic examination of the receptacles collected from the rock pool in August 1987 indicated that the distribution of the brown algal epiphytes was strongly and positively associated with conceptacles. From a total of 4761 conceptacles inspected, 500 $(9.5 \%)$ certainly contained epiphytes. These were mainly Ectocarpus and Myriactula species, which could occupy the same or separate conceptacles. From a total of 530 tufts of epiphytes observed on the receptacles, only $30(5.7 \%)$ were not plainly emergent from conceptacles.

The mechanism producing this pattern of distribution is almost certainly the process of skin-shedding or self-cleaning (Ducker \& Knox, 1984). The abscission of outer cell wall material is very active in growing and mature Himanthalia receptacles (Ende \& Oorschot, 1963; Russell \& Veltkamp, 1984) and may occur daily or even tidally. However, it does not take place inside the mouths of conceptacles, which hence become potentially vulnerable to epiphyte colonisation (Russell \& Veltkamp, 1984). On the other hand, the distribution of Herponema did not follow this pattern. This species formed spreading patches without obvious association with conceptacles, and its mode of infection remains uncertain.

The ability to invade a Himanthalia conceptacle affords at least one important advantage to the epiphyte. Rock pool Ectocarpus is particularly subject to grazing by isopod and amphipod crustacea which are numerous in summer. Their grazing appears to start with removal of distal portions of thallus (Fig. 6A) and then to proceed basipetally 


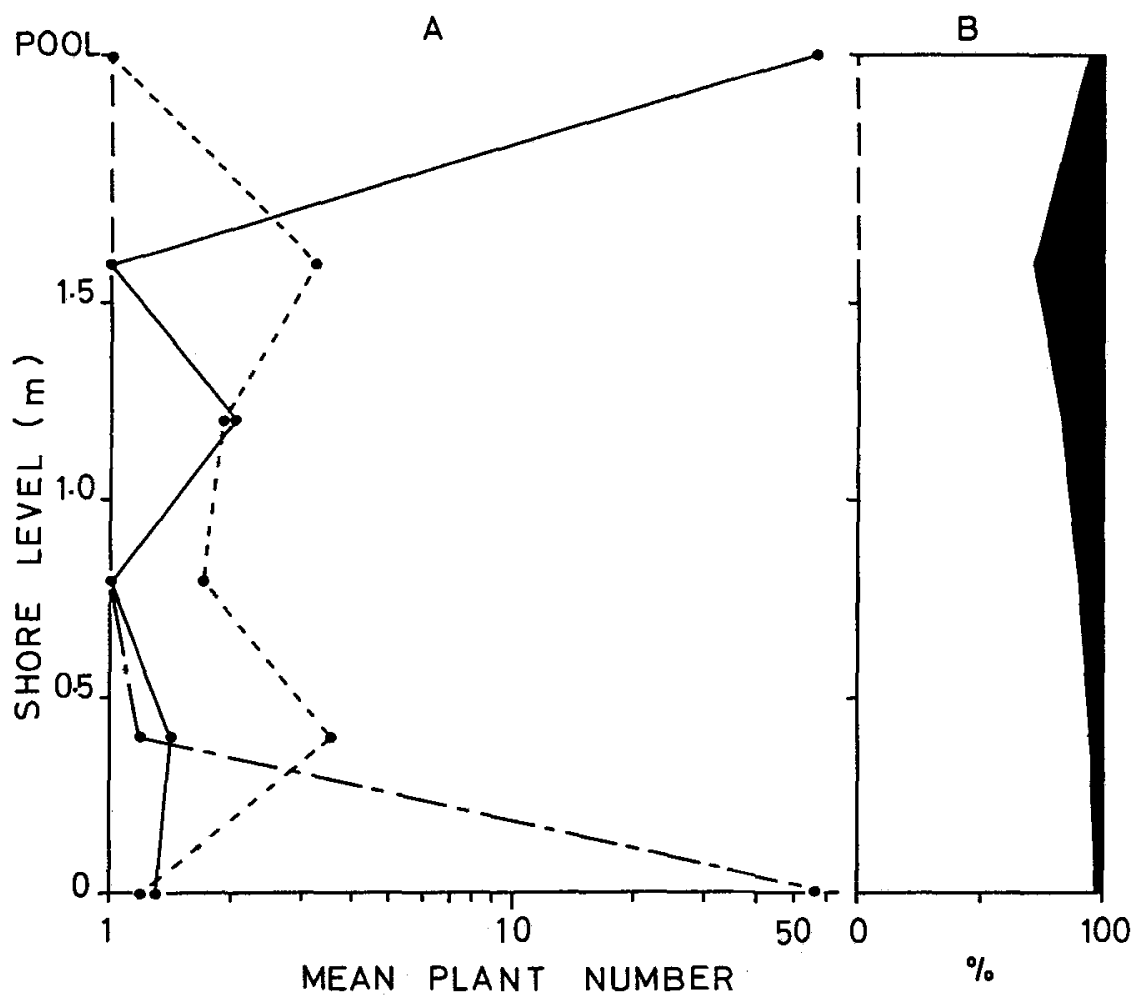

Fig. 5. A: Mean abundance of epiphytes (numbers of plants) present on Himanthalia receptacles at different shore levels in August 1987. Continuous line = Ectocarpus fasciculatus. Hatched line = Herponema velutinum. Dot-and-dash line $=$ Elachista scutulata. Mean values were calculated from epiphyte abundances on 30 replicate basiphytes at each shore level and 5 rock-pool basiphytes. B: Incidence of Red + Green algal epiphytes (shaded) and Brown algal epiphytes (unshaded) as percentages of total numbers of epiphytic plants on receptacles of Himanthalia from different shore levels. Port St Mary population, August 1987

to the ostiole (Fig. 6B, C). Regeneration of Ectocarpus can take place rapidly, however, when grazing pressure is reduced, e. g. in winter.

The survival of the other three species seems to be maintained by slightly different developmental features. The vegetative and reproductive parts of the Myriactula thallus are almost entirely contained within the basiphyte conceptacle. Sporangia of Herponema are produced in large numbers and in an almost continuous layer on the receptacle surface (Kuckuck, 1956), while those of Elachista are protected by a tissue of compacted vegetative filaments.

Evidently, the brown algal epiphytes of Himanthalia have a somewhat more specialised relationship with their host than those of Fucus vesiculosus in that they are highly specific to reproductive tissue. The disparity in size between receptacle and vegetative thallus is certainly very great and, for that reason alone, one would expect to find larger numbers of epiphytes on the former. However, zero incidence of most of these species on 


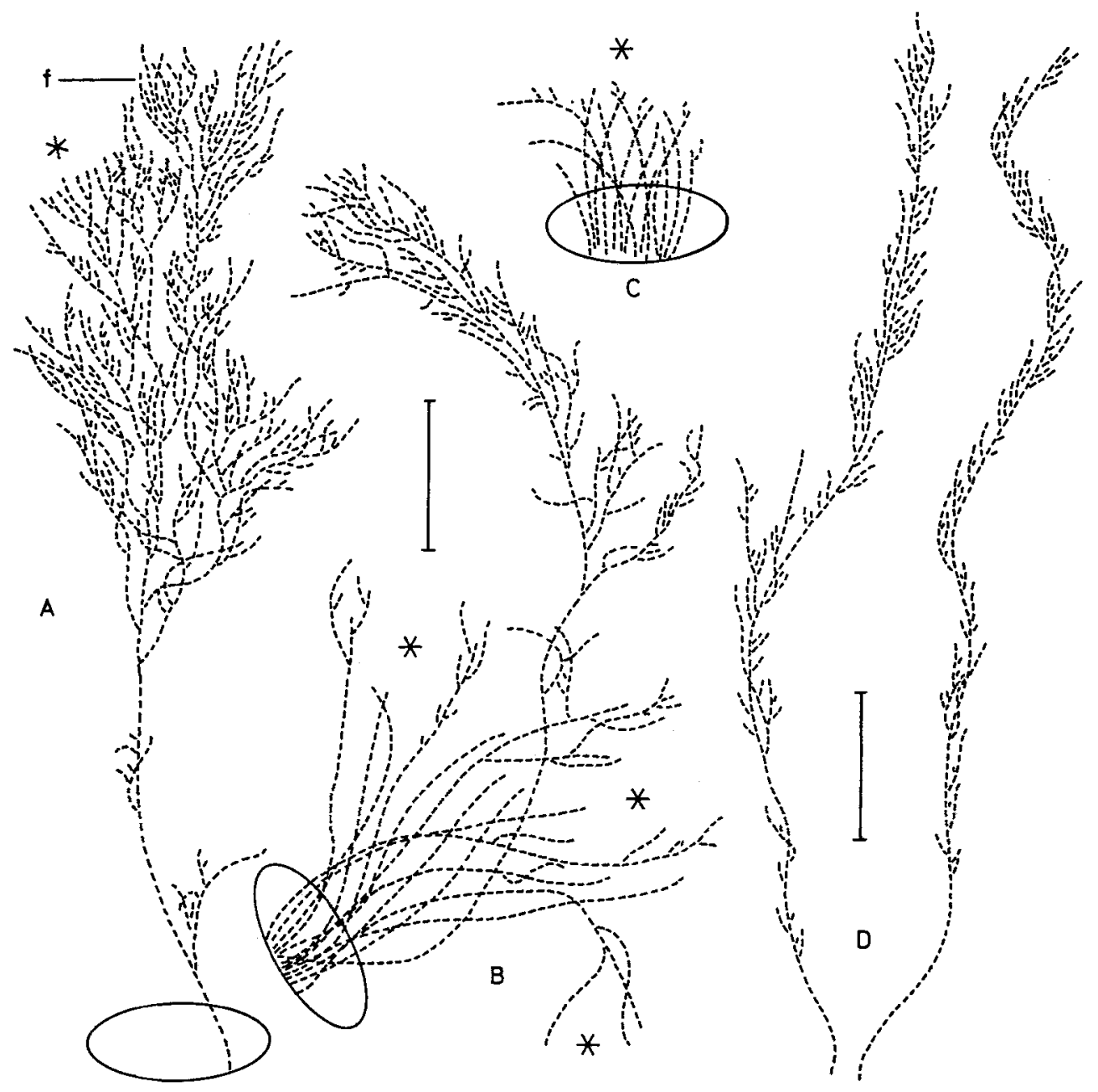

Fig. 6. A: Young Ectocarpus fasciculatus emerging from ostiole of Himanthalia conceptacle (ellipse) in summer 1987. $\mathrm{f}=$ branch fascicule; asterisk = grazing damage by rockpool crustacea. B: Heavily grazed Ectocarpus from rock-pool; only one upright filament has escaped damage. C: Ectocarpus grazed back almost to mouth of ostiole. D: Ectocarpus fasciculatus from Laminaria digitata, summer

1987. Note differences in morphology from population on Himanthalia (C). Scale bars $=1 \mathrm{~mm}$

the vegetative thallus would seem to denote the presence of a discriminatory factor in addition to size.

The self-cleaning mechanism producing the observed positive association between epiphytes and conceptacles seems only to function efficiently on growing and mature receptacles. The indiscriminate cover and species richness of epiphytes on the overwintered receptacles (Fig. $7 \mathrm{~b}$ ) would suggest that these structures no longer have any selfcleaning capacity. The number of overwintering receptacles is likely to vary with winter sea conditions and with the number of vegetative thalli reaching sexual maturity in the 


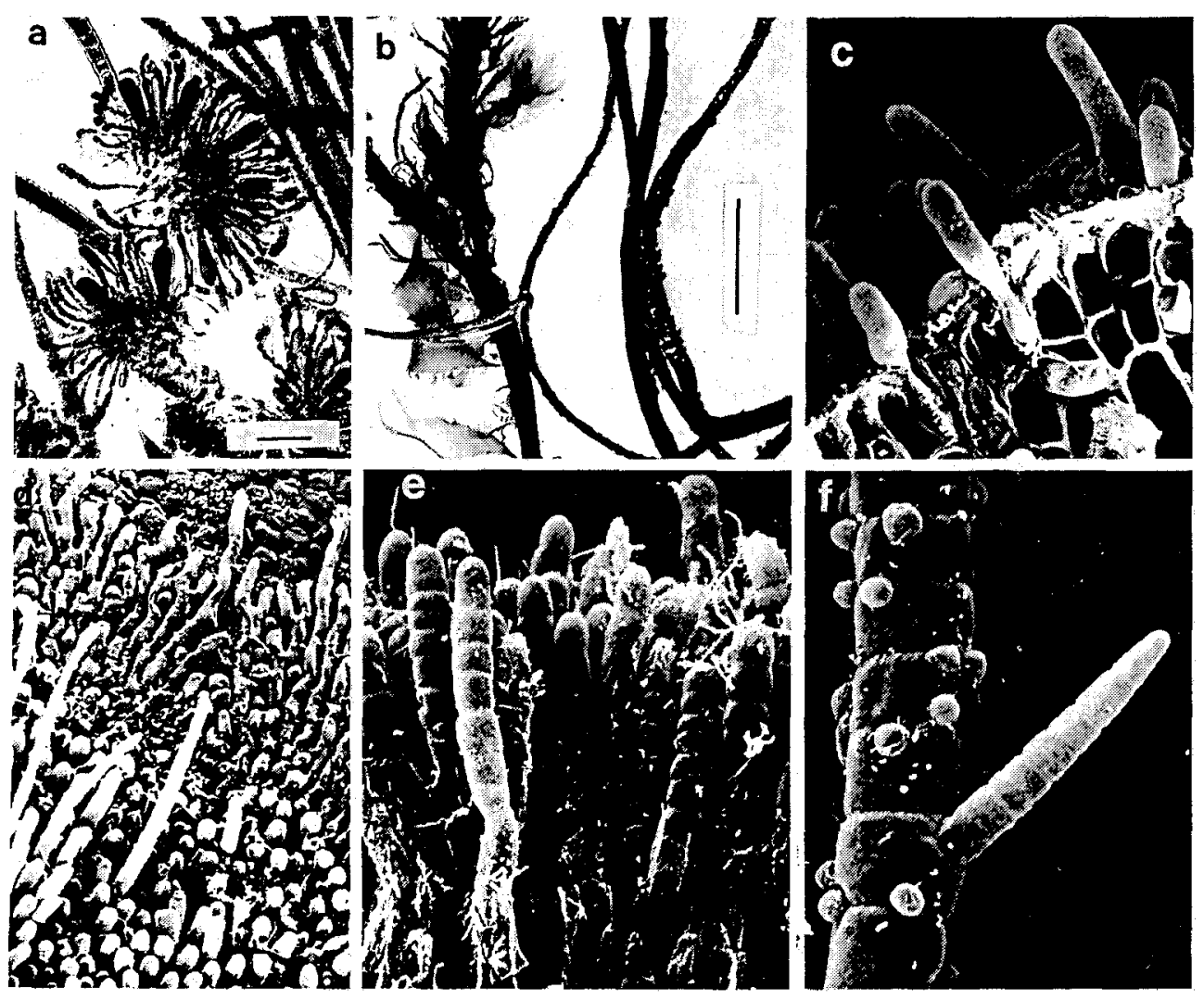

Fig. 7a. Squashed preparation of Elachista fucicola from receptacle of Fucus vesiculosus showing presence of unilocular sporangia. Scale bar $=100 \mu \mathrm{m}_{;} 7 \mathrm{~b}$. Himanthalia elongata receptacles from Port St Mary, summer 1987. Receptacle on left had overwintered from 1986, and carries a dense and varied epiflora. Receptacle on right is of the current year, and its epiflora is dominated by brown algae. Young Ectocarpus is emergent from some receptacle ostioles. Scale bar = approximately $5 \mathrm{~cm} ; 7 \mathrm{c}$. SEM preparation showing emergent ectocarpoid filaments from blade of Laminaria digitata, possibly of Ectocarpus fasciculatus. Scale bar $=10 \mu \mathrm{m} ; 7 \mathrm{~d}$. SEM preparation of procumbent ectocarpoid filaments on blade surface of $L$. digitata, possibly of E. fasciculatus. Scale bar $=10 \mu \mathrm{m}$;

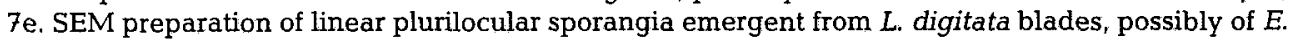
fasciculatus. Scale bar $=10 \mu \mathrm{m} ; 7 \mathrm{f}$. SEM preparation of $E$. fasciculatus showing initials of corticating filaments, homologous with those of microthalli. Scale bar $=10 \mu \mathrm{m}$

preceding season. On the basis of the 1986-87 observations, it seems possible that $5-10 \%$ of a receptacle cohort may persist over the winter following reproduction. These may nevertheless play a very important role in the sucessful transmission of epiphytes to new receptacles in their phase of early development between autumn and early spring (Gibb, 1937).

The results also indicate that epiphyte distribution may not be uniform throughout the basiphyte range, and it would seem possible that when basiphytes are growing under suboptimal conditions, e. $g$. at the limits of their range, they are more susceptible to infestation than those at the centre of distribution. However, seasonal and annual 
changes from the distribution pattern shown in Figure 5A for August 1987 are likely. Elachista scutulata, absent from the rockpool sample at that time can certainly be found there at other times and in other years.

\section{LAMINARIA DIGITATA (Huds.) Lamour.}

\section{Basiphyte populations}

Laminaria digitata is found abundantly on almost all Manx rocky shores, the principal exceptions being those of estuaries. It is the most conspicuous plant of the upper sublittoral zone in which it forms a more or less dense forest from E.L.W.S.T. to M.L.W.N.T. (Southward, 1953). However, its vertical distribution may be increased to higher levels of the eulittoral zone by exploitation of rock pools. As with Fucus vesiculosus, thallus morphology is strongly affected by wave action, the effects of which are most evident in the form of the blades. The most exposed localities are populated by plants with relatively long, narrow and deeply digitate blades (f. stenophylla Harv.) while the most sheltered sites are characterized by broad and relatively undivided blades (f. cucullata (Le Holis) Svendsen \& Kain). These form differences are evidently entirely plastic in origin (Sundene, 1964), and the range of blade morphs seems to be clinal rather than discontinuous in distribution. The following observations on epiphytes were made on the $L$. digitata population at Port St. Mary Ledges.

\section{Epiphyte population,}

The principal brown algal epiphyte of Manx Laminaria digitata is Ectocarpus fasciculatus Harv. According to Harvey (1871), the latter has a number of different species of basiphyte, including Himanthalia elongata, but $L$. digitata is its "favourite habitat". On Manx shores, most E. fasciculatus is borne by these two species, but its distribution and development on $L$. digitata follows a very different pattern from that on Himanthalia. On Laminaria it is common both on the perennial stipe and on the continually renewing blade tissues, the blade epiphytes being most frequent at the distal ends of the digits. This discontinuous distribution of Ectocarpus on the Laminaria thallus is a consequence of the intercalary meristems from which new blade and stipe tissue is produced. Thus Ectocarpus diaspores settling on the blade are conveyed distally by the processes of host thallus growth. Longterm success as an epiphyte is therefore enhanced by the ability to attain reproductive maturity before the supporting basiphyte tissues disintegrate at the blade tips (Russell, 1983a). In the event of reproductive failure by blade epiphytes, the stipe epiphytes provide a back-up source of additional diaspores. In practice, Ectocarpus maintains its presence on blade tips throughout the year, which implies that its pattern of seasonal development corresponds closely with that of the blade, as seems to be the case with epiphytes of Laminaria saccharina (L.) Lamour. (Russell, 1983a). Also, the distribution of E. fasciculatus on L. digitata is evidently unaffected by population differences in blade morphology (Russell, 1983a).

The undoubted success of $E$. fasciculatus as an epiphyte of $L$. digitata is certainly due in part to its ability to grow to reproductive maturity within the structural and develop- 
mental limitations imposed by the host. However, its success is greatly assisted by its morphological variability. In Ectocarpus from L. digitata, the primary and secondary branches are normally of lesser importance than the central thread which therefore remains visible throughout the length of the plant (Fig. 6D). The association of this form with $L$. digitata is evident also at Helgoland (Kornmann \& Sahling, 1977). The same species on Himanthalia has a spreading system of branches of gradually decreasing importance so that the identity of the original filament is quickly lost (Fig. 6A).

In addition to the two macrothalli, E. fasciculatus has two microthallus forms. One of these exists as pseudoparenchymatous discs, closely adherent to the outer surface of the Laminaria blade (Fig. 7d). This plant was originally identified as a myrionemoid phase of E. fasciculatus by Jaasund (1965) and subsequently isolated in culture by Baker \& Evans (1971). The second form consists of unfused filaments which ramify freely within the Laminaria blade tissues. This morph has also been grown in culture by Russell (1966) who referred to it as streblonemoid. Both types of microthallus can initiate macrothallus filaments in the field and in culture; and macrothallus can readily revert to microthallus in the form of corticating filaments (Fig. 7c, d, f).

Both types of microthalli become reproductive by producing linear plurilocular sporangia (Fig. $7 \mathrm{e}$ ), and the presence of such plants on Laminaria can pose considerable taxonomic problems. It is possible, as Jaasund (1965) has suggested, that the myrionemoid morph is conspecific with Myrionema corunnae Sauv., although Fletcher (1987) has argued a case for retaining the latter as a distinct species. The emergent sporangia of the streblonemoid morph cannot be distinguished easily from those of juvenile Laminariocolax tomentosoides (Farb.) Kylin, which is a "good" species, and Ectocarpus deformans (Dangeard, 1931) which is very dubious (Fig. 7e). It is likely that the taxonornic affinities of many of the ectocarpoid microthalli found on $L$. digitata can be resolved only by culture studies, and some may still remain a source of difficulty. However, the morphological versatility and reproductive phenology of E. fasciculatus are likely to be very important factors determining its success as an epiphyte.

\section{DISCUSSION}

The success of an epiphyte can be judged by the standards that would apply to an epilithic alga: it should be a consistently recurring member of its community and, though subject to natural fluctuations in population size, should be sufficiently numerous at some stage in its cycle of growth and reproduction to ensure its continued presence. For field observations of the kind made here, the term ecological cycle is perhaps more appropriate than life-cycle or life-history (see Dick, 1987 for redefinition of these). Accordingly, the observed epiphyte populations may be judged as successful.

A common feature of all these epiphytes is that their ecological cycles were well integrated with those of their basiphytes. It might be argued that such integration must be a product of evolutionary adaptation, but associations of epiphyte and basiphyte might come about more simply if the two have similar seasonal and environmental optima. The observation by Jephson \& Gray (1977) of the presence of native algal epiphytes on the recently introduced basiphyte Sargassum muticum (Yendo) Fensholt, and with integrated cycles of growth, would tend to support the latter interpretation. The reproductive fitness of the epiphytes likewise requires no hypothetical physiological relationship: 
other species of epiphyte with slower rates of reproductive maturation or with inappropriate reproductive phenologies would not be so successful on these basiphytes.

To identify high specificity of association with biochemical dependence could be equally mistaken. Elachista scutulata and Myriactula areschoungii are very host-specific, being known only from receptacle tissue of Himanthalia elongata (Fletcher, 1987), but this specificity could be a consequence of shared ecological optima as much as biochemical dependence. The fact that the non-specific epiphyte Ectocarpus fasciculatus could be as strongly associated with conceptacles of Himanthalia as Elachista scutulata and Myriactula areschougii illustrates how a specific epiphyte-basiphyte assocation might arise.

This is not to discount the possibility that some kind of host/recognition mechanism is possessed by these epiphytes. The epiphytic algae found on growing and mature receptacles of Himanthalia are, in terms of number of individuals, unexpectedly weighted in favour of brown algae (Fig. 5B). Himanthalia is a member of an algal community that is exceptionally rich in species of all major groups (Niell, 1977) and the number of diaspores available from these must be very high. It is therefore difficult to explain the Himanthalia epiflora entirely as a result of shared environmental optima. Perhaps basiphyte polyphenols, which are held by Sieburth \& Conover (1965) to retard fouling by epiphytes, are less effective inhibitors of phylogenetically related epiphytes. In a recent paper, Rönnberg \& Ruokolahti (1986) have questioned the effectiveness of Fucus vesiculosus polyphenols in controlling Elachista fucicola, its principal epiphyte.

A theory of epiphyte-basiphyte coevolution in freshwater vegetation has been proposed by Hutchinson (1975), and developed by Rogers \& Breen (1983). Hutchinson argues that epiphyton provides a major protection to the plants that bear it, in that herbivores graze preferentially upon the former. Consequently, organic exudates from the basiphyte are "... adaptive, leading to an increase in epiphytes that play the same sort of role in freshwater as do the chemical adaptations against excessive onslaughts of herbivores on land". This ingenious proposal may be applicable to freshwater ecosystems, but it runs counter to the evidence obtained from marine algal basiphytes, which evidently expend a considerable part of their production in the process of self-cleaning. Also, in the case of Himanthalia, any advantage gained from the diversion of grazing to the epiphytes may be offset by the numbers of conceptacles taken out of reproduction.

Of the species observed in the present study, it was the least host-specific epiphyte, Ectocarpus fasciculatus, which was associated with the largest number of identificatory problems. Of the various routes to epiphytic success perhaps morphological variability and plasticity is one, and strict maintenance of a fixed but fit genotype another. It is certain that the epiphyte-basiphyte relationship offers limitless and fascinating opportunities for future investigation.

Acknowledgements. I am grateful to R. J. Brown, A. Bullock, S. R. L. Hill, M. S. Leigh, A. Otto, A. J. Schofield, G. J. Thomas, C. E. Thorpe, C. V. Towner and H. J. White for assistance in the field. I am grateful also to D. G. Russell for help in the laboratory and, once again, to C. J. Veltkamp for S. E. M. 


\section{LITERATURE CITED}

Baker, J. R. J. \& Evans, L. V. 1971. A myrionemoid variant of Ectocarpus fasciculatus Harv. - Br. phycol. J. 6, 73-80.

Dangeard, P., 1931. Sur un Ectocarpus parasite provoquant des tumeurs chez le Laminaria flexicaulis Ectocarpus deformans nov. sp.). - C. r. hebd. Séanc. Acad. Sci., Paris, 192, 59-60.

Dick, M. W., 1987. Sexual reproduction: nuclear cycles and life-histories with particular reference to lower eukaryotes. - Biol. J. Linn. Soc. 30, 181-192.

Ducker, S. C. \& Knox, R. B., 1984. Epiphytism at the cellular level with special reference to algal epiphytes. In: Encyclopedia of plant physiology. N. S. Ed, by H.-F. Linskens \& J. HeslopHarrison. Springer, Berlin, 17, 113-133.

Ende, G. van den \& Oorschot, R. V., 1963. Weitere Beobachtungen über den Epiphytenbewuchs von Himanthalia elongata (L.) S. F. Gray. - Botanica mar. 5, 111-120.

Fletcher, R. L., 1987. Seaweeds of the British Isles. Vol. 3: Fucophyceae (Phaeophyceae) Part I. British Museum (Natural History), London, $359 \mathrm{pp}$.

Gibb, D. C., 1937. Observations on Himanthalia lorea (L.) Lyngb. - J. Linn. Soc. (Bot.) 51, $11-21$.

Harvey, W. H., 1871. Phycologia Britannica. Reeve, London, 1.

Hutchinson, G. E., 1975. A treatise on limnology. III: Limnological botany. Wiley, London, 660 pp.

Jaasund, E., 1965. Aspects of the marine algal vegetation of North Norway - Bot. Gothoburg. 4, $1-174$.

Jephson, N. A. \& Gray, P. W. G., 1977. Aspects of the ecology of Sargassum muticum (Yendo) Fensholt in the Solent region of the British Isles. I. The growth cycle and epiphytes. In: Biology of benthic organisms. Ed. by B. F. Keegan, P. O. Ceidigh \& P. J. S. Boaden. Pergamon Press, Oxford, $367-375$.

Knight, M. \& Parke, M. W., 1931. Manx algae. Liverpool Univ., Liverpool, 155 pp.

Knight, M. \& Parke, M., 1950. A biological study of Fucus vesiculosus L. and F. serratus L. - J. mar. biol. Ass. U. K. 29, 439-514.

Kornmann; P. \& Sahling, P.-H., 1977. Meeresalgen von Helgoland. Benthische Grün-, Braun- und Rotalgen. - Helgoländer wiss. Meeresunters. 29, 1-289.

Kuckuck, P., 1956. Ectocarpaceen-Studien IV. Herponema, Kutzingiella nov. gen., Farlowiella nov. gen. - Helgoländer wiss. Meeresunters. 5, 292-325.

Marshall, W., 1960. An underwater study of the epiphytes of Laminaria hyperborea (Gunn.) Fosl. Br. phycol. Bull. 2, 18-19.

Moss, B., 1952. Variation in chemical composition during the development of Himanthalia elongata (L.) S. F. Gray - J. mar. biol. Ass. U. K. 31, 29-34.

Niell, F. X., 1977. Rocky intertidal benthic systems in temperate seas: A synthesis of their functional performances. - Helgoländer Meeresunters., 30, 315-333.

Norton, T. A., Hiscock, K. \& Kitching, J. A., 1977. The ecology of Lough Ine. XX. The Laminaria forest at Carrigathorna. - J. Ecol. 65, 919-941.

Novak, R., 1984. A study in ultra-ecology: microorganisms on the seagrass Posidonia oceanica (L.) Delile. - Mar. Ecol. 5, 143-190.

Orth, R. J. \& Montfrans, J. van, 1984. Epiphyte-seagrass relationships with an emphasis on the role of micrograzing: A review. - Aquat. Bot. 18, 43-69.

Rogers, K. H. \& Breen, C. M., 1983. An investigation of macrophyte, epiphyte and grazer interactions. In: Periphyton of freshwater ecosystems. Ed. by R. G. Wetzel. Junk, The Hague, 217-226.

Rönnberg, O. \& Ruokolanti, C., 1986. Seasonal variation of algal epiphytes and phenolic content of Fucus vesiculosus in a northern Baltic archipelago - Ann. bot. fenn., 23, 317-323.

Russell, G., 1966. The genus Ectocarpus in Britain. I. The attached form - J. mar. biol. Ass. U. K. 46, 267-294.

Russell, G., 1979. Heavy receptacles in estuarine Fucus vesiculosus L. - Estuar. coast. mar. Sci. 9, $659-661$.

Russell, G., 1983a. Formation of an ectocarpoid epiflora on blades of Laminaria digitata - Mar, Ecol. Progr. Ser. 11, 181-187.

Russell, G., 1983b. Parallel growth patterns in algal epiphytes and Laminaria blades. - Mar. Ecol. Progr. Ser. 13, 303-304. 
Russell, G., 1985. Recent evolutionary changes in the algae of the Baltic Sea - Br. phycol. J. 20, 87-104.

Russell, G. \& Veltkamp, C. J., 1984. Epiphyte survival on skinshedding macrophytes. - Mar. Ecol. Progr. Ser. 18, 149-153.

Sieburth, J. M. \& Conover, J. T., 1965. Sargassum tannin, an antibiotic which retards fouling. Nature, Lond., 208, 52-53.

Silvertown, J., 1987. Plant population ecology. Longman, Harlow, 229 pp.

Southward, A. J., 1953. The ecology of some rocky shores in the south of the Isle of Man. - Proc. Trans. Lpool. biol. Soc. 59, 1-50.

Sundene, O., 1964. The ecology of Laminaria digitata in Norway in view of transplant experiments. Nytt Mag. Bot. 11, 83-107.

Tokida, J., 1960. Marine algae epiphyte on Laminariales plants. - Bull. Fac. Fish. Hokkaido Univ. 11, 73-105.

Wetzel, R. G., 1983. Recommendations for future research on periphyton. In: Periphyton of freshwater ecosystems. Ed. by R. G. Wetzel. Junk, The Hague, 339-346. 